\title{
KARAKTERISTIK DAN LAMA PENGGUNAAN KONTRASEPSI DEPOT MEDROXYASETAT (DMPA) DENGAN KUALITAS HIDUP AKSEPTOR
}

\section{CHARACTERISTICS AND DURATION OF USE CONTRACEPTION DEPOT MEDROXYASETAT (DMPA) WITH ACCEPTOR'S LIFE QUALITY}

\author{
Aprilina*, Yunetra Franciska \\ Politeknik Kesehatan Kementerian Kesehatan Palembang \\ *) E-mail aprilina@poltekkespalembang.ac.id
}

\begin{abstract}
Depot Medroxy Progesterone Acetate (DMPA) is a highly effective, safe, can be used by all women in reproductive age, the return of fertility is slower for an average of 4 months and is suitable for breastfeeding women because it does not suppress milk production. Many of the effects of DMPA that may be experienced include vaginal dryness, decreased libido, emotional distress, headache, nervosity, acne, can decrease bone mineral density, thus increasing the risk of bone fracture (osteoporosis). The many side effects experienced by DMPA contraceptive acceptors are feared will affect their quality of life. The purpose of this research was to analyze the correlation between characteristic and duration of use with quality of life on contraceptive acceptor deproverrootacetate (DMPA) at Bidan Praktik Mandiri Palembang. This research uses cross sectional research design, research time of June-November year 2017. The place of this research is done in BPM Palembang city. Research respondents are all DMPA contraceptive acceptors who have met the inclusion and exclusion criteria. Sampling technique is using simple random sampling. Data collection techniques are using biodata questionnaire, WHOQOL-BREF Questionnaire. Analysis of univariate data with frequency distribution and bivariate with Chi-Square statistical test. The result of this research shows that there is only significant correlation between respondent age with domain 3 (psychological state) quality of life acceptors that is with value $\rho$ value 0,02 , meaningful relationship between duration of contraception use with domain 3 (psychological state) quality of life acceptors with value $\rho$ value 0,02 , and there is significant relation between age of respondent with domain 4 (environment) quality of life acceptors with value $\rho$ value 0,03 . Conclusions can be seen that the results of analysis not all domains of quality of life (physical health, psychological, social relations, environment) if associated with the characteristics and duration of contraceptive use have a meaningful relationship.
\end{abstract}

Keywords: characteristics, duration of use, contraception DMPA, Quality of life.

\section{ABSTRAK}

Depot Medroxy Progesterone Acetate (DMPA) merupakan kontrasepsi injeksi progestin yang sangat efektif, aman, dapat dipakai oleh semua perempuan dalam usia reproduksi, kembalinya kesuburan lebih lambat rata-rata 4 bulan dan sangat cocok untuk wanita menyusui karena tidak menekan produksi ASI. Banyak efek penggunaan DMPA yang mungkin akan dialami. Banyaknya efek samping yang dialami oleh para akseptor kontrasepsi DMPA dikhawatirkan akan mempengaruhi kualitas hidup mereka.Tujuan penelitian untuk menganalisis hubungan antara karakteristik dan lama penggunaan dengan kualitas hidup pada akseptor kontrasepsi depot mendroxyasetat (DMPA) di Bidan Praktik Mandiri Palembang dilihat berdasarkan 4 aspek/domain. Penelitian ini menggunakan desain penelitian Cross sectional, waktu penelitian bulan Juni-Nopember tahun 2017. Tempat penelitian di BPM wilayah kota Palembang. Responden adalah semua akseptor kontrasepsi DMPA yang telah memenuhi kriteria inklusi dan eksklusi. Tehnik pengambilan sampel yaitu menggunakan simpel random sampling. Tehnik pengumpulan data menggunakan kuesioner biodata, WHOQOL-BREF Questionnaire. Analisis data univariat dengan distribusi frekuensi dan bivariat dengan uji statistik ChiSquare. Hasil penelitian ini menunjukkan ada hubungan yang bermakna antara usia responden dengan domain 3 (keadaan psikologis) kualitas hidup akseptor yaitu dengan nilai $\rho$ value 0,02 , hubungan yang bermakna antara lama penggunaan kontrasepsi dengan domain 3 (keadaan psikologis) kualitas hidup akseptor dengan nilai $\rho$ value 0,02 , dan ada hubungan yang bermakna antara usia responden dengan domain 4 (lingkungan) kualitas hidup akseptor dengan nilai $\rho$ value 0,03 . Kesimpulan dapat dilihat bahwa dari hasil analisis tidak semua domain kualitas hidup (kesehatan fisik, psikologis, hubungan sosial, lingkungan) jika dihubungkan dengan karakteristik dan lama penggunaan kontrasepsi memiliki hubungan yang bermakna.

Kata Kunci: Karakteristik, Kualitas hidup,kontrasepsi DMPA, lama penggunaan

\section{PENDAHULUAN}

Depot Medroxy Progesterone

Acetate (DMPA) merupakan kontrasepsi injeksi progestin yang sangat efektif, aman, dapat dipakai oleh semua perempuan dalam usia reproduksi, kembalinya kesuburan lebih lambat rata-rata 4 bulan dan sangat cocok untuk wanita menyusui karena tidak menekan produksi ASI.
Kontrasepsi DMPA terdapat pada kontrasepsi suntik Depo Provera, mengandung $150 \mathrm{mg}$ DMPA yang diberikan setiap 3 bulan dengan cara disuntik intramuskuler (di daerah bokong). (Saifuddin, 2011). Metode kontrasepsi hormonal progestin semula diperkenalkan untuk menghindari efek samping estrogen dan menurunkan pajanan total ke steroid. 
Dengan adanya regimen estrogenprogesteron modern dosis rendah, alasan ini kurang menjadi masalah tetapi pendekatan dengan metode progestin ini telah mendorong berkembangnya sejumlah metode bermanfaat yang memiliki masa kerja yang sangat lama dan dosis pajanan steroid yang rendah, sementara efektivitas kontrasepsi tetap tinggi. Setiap metode kontrasepsi progestin memiliki keunggulan dan daya tarik yang berbeda-beda bagi penggunanya. (Glasier A, 2005, Bahri Narjes, dkk. 2016).

Kontrasepsi DMPA memiliki beberapa keuntungan diantaranya efektivitas yang tinggi, dengan 0,3 kehamilan per 100 perempuan per tahun, asal penyuntikannya dilakukan secara teratur sesuai jadwal yang telah ditentukan, Tidak mengandung estrogen, progestin menekan pengeluaran follicle stimulating hormone (FSH) dan luteinizing hormone (LH), sehingga tidak berdampak serius terhadap penyakit jantung, dan gangguan pembekuan darah. (Saifuddin, 2011, Glasier A, 2005, Prior Jerilynn C, 2001 )

$$
\text { Banyak penelitian yang }
$$

mengemukakan efek dari penggunaan kontrasepsi progestin terutama penggunaan dalam jangka waktu yang lama karena metode ini tanpa kandungan esterogen. Efek penggunaan DMPA mungkin akan dialami dalam waktu beberapa bulan setelah penyuntikan terakhir sebelum benar-benar hilang, sehingga terjadi penundaan pemulihan kesuburan yang lamanya sulit diperkirakan. menimbulkan kekeringan pada vagina, menurunkan libido, gangguan emosi, sakit kepala, nervositas, jerawat, dapat menurunkan kepadatan mineral tulang sehingga meningkatkan risiko fraktur tulang (osteoporosis). Banyaknya efek samping yang dialami oleh para akseptor kontrasepsi DMPA dikhawatirkan akan mempengaruhi kualitas hidup mereka. (Saifuddin, 2011, Glasier A, 2005, Banks Emily, 2001, Bahamondes L, 2006)

Kualitas hidup menjadi suatu pertimbangan penting untuk mengevaluasi berbagai hasil akhir efektifitas dari pelayanan kesehatan yang diberikan para profesional dalam menentukan berbagai manfaat dari macam opsi/pilihan tindakan medis yang akan diberikan kepada para pasiennya.(Afiyanti, 2010, Pradono J, Hapsari D, dan Sari P, 2009) $\begin{array}{ccc}\text { Berdasarkan data } & \text { SDKI } 2012 \\ \text { peningkatan } & \text { penggunaan }\end{array}$ kontrasepsi suntik progestin dari $12 \%$ (SDKI 1991) menjadi 32\% (SDKI 2012) dan Profil Kesehatan Kota Palembang tahun 2013 menunjukkan proporsi peserta KB aktif menurut jenis kontrasepsi pengguna kontrasepsi suntik sebesar 45,59\%, kemudian pada tahun 2015 meningkat menjadi $46,40 \%$ hal ini menunjukkan bahwa kontrasepsi suntik masih yang paling banyak diminati dari tahun ke tahun.(kemenkes, 2012, palembang, 2015)

Meningkatnya jumlah akseptor kontrasepsi injeksi DMPA sehingga perlu dilakukan evaluasi terhadap kualitas hidup wanita akseptor kontrasepsi DMPA tersebut sehingga dapat dilakukan usaha preventif untuk mencegah terjadinya efek yang merugikan kesehatan akseptor.

\section{METODE}

Penelitian ini menggunakan desain penelitian observasional dengan rancangan studi Cross-sectional. Penelitian dilaksanakan di beberapa Bidan Praktik Mandiri yang berada wilayah kota Palembang. Dilaksanakan pada bulan Juni - Nopember 2017. Populasi penelitian adalah semua akseptor kontrasepsi DMPA yang melakukan kunjungan di BPM Tahun 2017. Sampel penelitian yaitu semua akseptor kontrasepsi DMPA yang melakukan kunjungan ke BPM pada bulan Agustus-Nopember Tahun 2017. Besar sampel dalam penelitian ini diambil dengan menggunakan rumus sederhana menurut Notoatmodjo yaitu didapatkan sampel minimal sebanyak 57 orang responden, menurut Borg dan Gall dalamDelice, 2010 bahwauntukpenelitian relational survey design jumlahsampeltidakbolehkurangdari 30 responden. Tehnik pengambilan responden dalam penelitian ini menggunakan tehnik simple random sampling. Pada penelitian ini, untuk mengukur kualitas hidup responden peneliti menggunakan kuesioner WHOQOL-BREF. WHOQOL-BREF ini sudah digunakan di 23 negara pada usia dewasa. (Oktavianus $\mathrm{Ch}$. S, 2007).

Analisis data berupa analisis univariat masing-masing variabel yaitu frekuensi, persentase. Analisis bivariate dilakukan untuk menganalisishubungan karakteristik responden, dan lama penggunaan kontrasepsi dengan kualitas hidup akseptor kontrasepsi DMPA. Analisis 
yang digunakan analisis komparatif $>2$ kelompok tidak berpasangan yaitu uji Chisquare karena variabel dependen dan independennya merupakan kategorik. Confident Intervalnya yaitu 95\%. (Dahlan MS, 2011)

\section{HASIL}

Penelitian ini telah dilakukan dari bulan Juni 2017 sampai dengan Nopember 2017 di Bidan Praktik Mandiri (BPM) yang berada diwilayah kota Palembang yaitu BPM Teti Herawati, BPM CH Mala, BPM Nurtila, BPM Liesiana Puspitasari terhadap 75 orang responden akseptor kontrasepsi DMPA yang melakukan kunjungan ulang dibulan November sampai Desember tahun 2017. Subjek penelitian ini sudah memenuhi sampel minimal yaitu sebanyak 57 orang.

Sebagian besar responden berusia kategori risiko rendah yaitu sebesar $74,4 \%$, berpendidikan tinggi yaitu sebesar $73,3 \%$, bekerja yaitu sebesar $76 \%$, berpenghasilan rendah yaitu sebesar $54,7 \%$ dan menggunakan kontrasepsi DMPA lebih dari sama dengan 2 tahun yaitu sebesar $74,7 \%$.

\section{PEMBAHASAN}

Domain 1 merupakan kesehatan fisik yaitu penyakit dan kegelisahan, tidur dan beristirahat, energi dan kelelahan, mobilitas, aktivitas sehari-hari, ketergantungan pada obat dan bantuan medis, kapasitas pekerjaan.

Moons, Marquet, Budst, dan de Geest (2004) dan Dalkey (2002) mengatakan bahwa usia adalah salah satu faktor yang mempengaruhi kualitas hidup. Hasil uji analisistidak ada hubungan yang bermakna usia responden dengan domain 1 (kesehatan fisik) kualitas hidup dimana nilai $\rho>0,05$ yaitu sebesar 1,00 . Seiring bertambahnya usia seseorang lebih rentan mengalami berbagai penyakit, namun jarang menyebabkan penyakit serius sebelum 40 tahun dan meningkat 5 kalilipat pada usia 40 sampai 60 tahun (Price \& Wilson, 2006). Penelitian yang dilakukan oleh Rugerri, M, Warner. R, Bisoffi, G. \& Fontecedro, $L$ (2001), pada responden berusia tua menemukan adanya kontribusi dari faktor usia terhadap kualitas hidup subjektif individu yang disebabkan karena individu pada masa usia tua sudah melewati masa untuk melakukan perubahan dalam hidupnya sehingga mereka cenderung mengevaluasi hidupnya dengan lebih positif dibandingkan saat masa mudanya. (Nofitri, 2009, Larasati T, 2007)

Hasil uji chi square menunjukkan tidak ada hubungan yang bermakna antara pendidikan responden dengan domain 1 (kesehatan fisik) kualitas hidup dimana nilai $\rho$ value $>0,05$ yaitu sebesar 0,75. Penelitian yang dilakukan oleh Noghani, Asgharpour, Safa, dan Kermani (2007) menemukan adanya pengaruh positif dari pendidikan terhadap kualitas hidup subjektif namun tidak banyak. (Nofitri, 2009)

Tidak ada hubungan yang bermakna antara pekerjaan dengan domain 1 (kesehatan fisik) kualitas hidup dimana nilai $\rho$ value > 0,05 yaitu sebesar 0,32. Penelitian yang dilakukan Wahl, Rustoen, Hanestad, Lerdal \& Moum (2004) menemukan bahwa status pekerjaan berhubungan dengan kualitas hidup baik pada pria maupun wanita (Nofitri, 2009, Larasati, 2007)

Tidak ada hubungan yang bermakna antara penghasilan dengan domain 1 kualitas hidup dimana nilai $\rho$ value $>0,05$ yaitu sebesar 0,72. Baxter, dkk (1998) dan Dalkey (2002) menemukan adanya pengaruh dari faktor demografi berupa penghasilan dengan kualitas hidup yang dihayati secara subjektif. Penelitian yang dilakukan oleh Noghani, Asgharpour, Safa, dan Kermani (2007) juga menemukan adanya kontribusi yang lumayan dari faktor penghasilan terhadap kualitas hidup namun tidak banyak. Dan menurut Cohen \& Lazarus kualitas hidup seseorang dapat dinilai dari intelektual dan kondisi materinya. (Nofitri, 2009, Larasati, 2007)

Tidak ada hubungan yang bermakna antara lama penggunaan kontrasepsi DMPA dengan domain 1 (kesehatan fisik) kualitas hidup dimana nilai $\rho$ value $>0,05$ yaitu sebesar 0,25. Asumsi peneliti bahwa semakin lama seorang akseptor menggunakan salah satu kontrasepsi, maka hal ini menandakan bahwa semakin dirasakan nyaman oleh si akseptor dengan demikian kualitas hidup tidak akan terganggu dan dirasakan baik.

Domain 2 merupakan keadaan psikologis yaitu terdiri dari perasaan positif, berfikir; belajar; mengingat; dan konsentrasi, self-esteem, penampilan dan gambaran jasmani, perasaan negatif, kepercayaan individu.

Mayoritas responden memiliki psikologis yang stabil sehingga berdampak 
pada kualitas hidup yang tinggi yaitu sebesar 78,7\%. Guru besar emeritus bidang Psikologis Klinis Fakultas Psikologi (Fapsi) Unpad, Prof. Dr. H. Soetardjo A. Wiramihardja, mengungkapkan bahwa kesehatan mental (mental health) terkait dengan kondisi jiwa dan perilaku yang sehat. Mental health juga terkait dengan mental hygiene yang mendukung tubuh menjadi sehat (healthy life), jika kondisi tersebut telah dimiliki oleh seseorang, maka akan tercipta kualitas hidup yang baik (quality of life). (unpad, 2013)

Tidak ada hubungan yang bermakna antara usia responden dengan domain 2 (psikologis) kualitas hidup dimana nilai $\rho$ value $>0,05$ yaitu sebesar 0,21 . Kesehatan psikologis mengacu pada asfek positif, spiritualitas, berfikir, belajar, memori dan konsentrasi, gambaran diri dan penampilan, harga diri, dan afek negatif (WHO, 1996; Rapley, 2003). Tugas-tugas dalam perkembangan merupakan pola perilaku yang disetujui pada berbagai usia sepanjang rentang kehidupan. Tugas yang muncul pada saat atau sekitar suatu periode tertentu dari kehidupan individu, yang jika berhasil akan menimbulkan rasa bahagia dan membawa ke arah keberhasilan dalam melaksanakan tugastugas berikutnya. Akan tetapi, apabila gagal akan menimbulkan kesulitan dalam menghadapi tugas berikutnya. (Rohmah Ain, Purwaningsih, Bariyah K, 2012).

Tidak ada hubungan yang bermakna antara pendidikan dan domain 2 (keadaan psikologis) dimana nilai $\rho$ value $>0,05$ yaitu sebesar 0,11. Sebagian besar responden pada penelitian ini berpendidikan tinggi. Pendidikan dapat membentuk kecerdasan emosional. Seseorang yang memiliki kecerdasan emosional tinggi akan mampu menguasai diri, mengelola emosi, memotivasi diri dan mengarahkan dirinya untuk lebih produktif dalam berbagai hal yang dikerjakan. Apabila kecerdasan emosionalnya rendah maka orang akan menjadi cemas, menyendiri, sering takut, merasa tidak dicintai, merasa gugup, sedih dan cenderung mudah terkena depresi. Sehingga dapat mempengaruhi kepuasan dalam hidup dan menjadi salah satu faktor yang ikut berperan untuk menurunkan kualitas hidup. Seseorang yang kondisi spiritualnya baik, mekanisme kopingnya akan lebih baik sehingga dia mampu menyelesaikan semua permasalahan hidupnya. Kondisi ini akan mendukung individu tersebut untuk mencapai kesejahteraan psikologis sehingga akan berpengaruh pada peningkatan kualitas hidupnya. (Rohmah Ain, Purwaningsih, Bariyah K, 2012, Larasati T, 2007).

Tidak ada hubungan yang bermakna antara pekerjaan dan domain 2 (keadaan psikologis) dimana nilai $\rho$ value $>0,05$ yaitu sebesar 0,51. Hal ini berbeda dengan penelitian yang dilakukan Yulidasari $F$, dkk dimana terdapat hubungan antara status pekerjaan ibu dengan pemilihan kontrasepsi suntik $(p=0,031)$. Penelitian yang dilakukan oleh Panuntun dkk bahwa terdapat hubungan antara pekerjaan dengan pemilihan alat kontrasepsi hormonal (suntik). Kontrasepsi non hormonal lebih banyak dipilih pada responden yang berpenghasilan rendah dan tidak bekerja. Hal ini berkaitan secara langsung dengan tingkat penghasilan responden dalam menentukan kontrasepsi yang mampu untuk dibeli sehingga tidak memberatkan si pengguna atau dalam hal ini akseptor. Jika dihubungkan dengan kualitas hidup pada domain 2 (psikologis) tidak terdapat hubungan yang bermakna dimana nilai $\rho$ value $>0,05$ yaitu sebesar 0,48 sehingga penghasilan tidak akan mempengaruhi kualitas hidup responden. Kestabilan kesejahteraan psikologis menjadi salah satu faktor yang ikut berperan dalam meningkatkan kesejahteraan psikologis (Renwick \& Brown, 1996) dalam (Rohmah Ain, Purwaningsih, Bariyah K, 2012).

Tidak ada hubungan yang bermakna antara lama penggunaan kontrasepsi DMPA dengan domain 2 kualitas hidup dimana nilai $\rho$ value $>0,05$ yaitu sebesar 0,36 . Hal ini menunjukkan bahwa sebagian besar responden walaupun telah lama menggunakan kontrasepsi tidak menunjukkan atau tidak merasakan gangguan pada psikologisnya hal ini menunjukkan bahwa pasien nyaman dengan kontrasepsi yang dipilihnya sehingga kualitas hidup dirasakan baik.

Domain 3 dari kualitas hidup adalah hubungan sosial yang meliputi hubungan pribadi, dukungan sosial, aktivitas seksual. Kualitas hidup dikenal sebagai indikasi level fungsi sosial pada kesehatan mental (Menlowics \& Stein, 2000; Shahrir, dkk, 2006).

Ada hubungan yang bermakna antara usia responden dengan domain 3 kualitas hidup dimana nilai $\rho$ value $<0,05$ 
yaitu sebesar 0,02. Teori mengatakan bahwa semakin bertambahnya usia, kegiatan sosial pun semakin berkurang. Disebut juga sebagai "social disengagement", yaitu suatu proses pengunduran diri secara timbal balik pada masa lanjut usia dan lingkungan sosial (Kalish, 1976; Hurlock, 2002). Kurang harmonisnya hubungan sosial menjadi penyebab rendahnya kualitas hidup seseorang. (Rohmah Ain, Purwaningsih, Bariyah K, 2012).

Hubungan antara Pendidikan responden dengan domain 3 kualitas hidup menunjukkan hubungan yang tidak bermakna dimana nilai $\rho$ value $>0,05$ yaitu sebesar 0,75 . Pada dasarnya, semakin tinggi pendidikan seseorang maka semakin banyak pengetahuan yang dimilikinya sehingga semakin rasional menggunakan alat kontrasepsi. Secara teori diketahui bahwa pengetahuan mempunyai kontribusi besar dalam mengubah perilaku seseorang dalam berbuat sesuatu, hal ini termasuk dalam hubungan sosial untuk berhubungan sosial dengan masyarakat atau komunitas seseorang membutuhkan pengetahuan yang baik. (Larasati T, 2007, Maiharti RI, Kuspriyanto, 2012)

Pekerjaan dan penghasilan dalam penelitian ini sama-sama tidak ada hubungan yang bermakna dimana nilai $\rho$ value $>0,05$ yaitu pekerjaan $(1,00)$ dan penghasilan $(0,88)$. Hal ini berarti kualitas hidup tidak berhubungan dengan pekerjaan dan penghasilan seseorang dalam berhubungan sosial. Hubungan antara Lama Penggunaan kontrasepsi DMPA dengan domain 3 menunjukkan hubungan yang bermakna dimana nilai $\rho$ value $>0,05$ yaitu sebesar 0,02. Hal ini tidak sejalan dengan penelitian yang dilakukan oleh Bahri $\mathrm{N}$, dkk dimana terdapat hubungan yang bermakna antara lama penggunaan kontrasepsi dengan domain 3 (hubungan sosial) kualitas hidup dengan $\rho$ value 0,33 . Penelitian yang dilakukan Raymond, dkk terhadap 361 wanita akseptor kontrasepsi pil kombinasi (87 orang), injeksi (67 orang), IUD (96 orang), dan MOW (111 orang) untuk mengetahui hubungan pemakaian kontrasepsi tersebut terhadap fungsi sexual responden didapatkan hasil tidak ada hubungan yang bermakna dimana $\rho$ value $>0,05$. (Bahri Narjes, dkk. 2016, Raymond HW, dkk.2004, Matsumoto Y, Y. S., Ideta K, Kawabata M, 2007)
Domain 4 pada kualitas hidup merupakan keadaan lingkungan yang meliputi kebebasan; keselamatan fisik dan keamanan, lingkungan rumah, sumber keuangan, kesehatan dan kepedulian sosial, peluang untuk memperoleh keterampilan dan informasi baru, keikutsertaan dan peluang untuk berekreasi, aktivitas di lingkungan, transportasi.

Hubungan antara usia responden dengan domain 4 kualitas hidup menunjukkan hubungan yang bermakna dimana nilai $\rho$ value $<0,05$ yaitu sebesar 0,03 . Kualitas hidup individu berkaitan secara intrinsik dengan kualitas hidup orang lain yang berada dilingkungannya. Hal ini didukung oleh pendapat Goode (1994; Nuran, 2009) bahwa kualitas hidup seseorang merefleksikan kekayaan kultural dari seseorang dan mereka yang berada di sekitarnya. Lingkungan yang baik akan mendukung individu dalam melaksanakan aktivitas kehidupan sehari-hari. Terciptanya suasana tempat tinggal yang asri dan menyenangkan untuk ditinggali sangat bergantung pada interaksi para anggota di dalamnya yang memiliki komitmen bersama antar sesama anggota dan sadar akan tugas dan kewajibannya masing-masing. Dengan tercapainya kesejahteraan lingkungan akan mendukung individu dalam memperoleh kualitas hidup yang maksimal. Hubungan antara pendidikan responden dengan domain 4 kualitas hidup menunjukkan hubungan yang tidak bermakna dimana nilai $\rho$ value $>0,05$ yaitu sebesar 0,33 . Semakin tinggi pendidikan seseorang maka akan mudah dalam beradaptasi dilingkungan manapun ia berada.

Hubungan antara pekerjaan dan penghasilan akan berjalan beriringan terutama dalam hal domain 4 kualitas hidup responden. Memiliki pekerjaan yang baik, biasanya akan diikuti dengan penghasilan yang baik pula dengan kondisi penghasilan atau pendapatan yang baik, maka pemilihan tempat tinggal akan lebih selektif lagi. Dengan penghasilan yang cukup individu akan berusaha memilih tempat tinggal atau lingkungan yang baik dimana ia dan keluarga akan tinggal. Pada penelitian ini hubungan pekerjaan dan penghasilan responden dengan domain 4 kualitas hidup menunjukkan hubungan yang tidak bermakna dimana sama-sama nilai $\rho$ value $>0,05$ yaitu sebesar 1,00 . 
Hubungan antara lama penggunaan kontrasepsi DMPA dengan domain 4 kualitas hidup menunjukkan hubungan yang tidak bermakna dimana nilai $\rho$ value $>0,05$ yaitu sebesar 0,17 . Hal ini berarti lama penggunaan kontrasepsi tidak berhubungan dengan kualitas hidup akseptor khususnya pada domain 4 yaitu aspek lingkungan.

\section{KESIMPULAN}

Tidak terdapat hubungan antara karakteristik dan lama penggunaan kontrasepsi DMPA dengan domain 1 (kesehatan fisik) kualitas hidup akseptor kontrasepsi depot medroxyasetat (DMPA) di Bidan Praktik Mandiri Palembang.

Tidak terdapat hubungan antara karakteristik dan lama penggunaan kontrasepsi DMPA dengan domain 2 (psikologis) kualitas hidup akseptor kontrasepsi depot medroxyasetat (DMPA) di Bidan Praktik Mandiri Palembang.

Terdapat hubungan antara usia responden dan lama penggunaan kontrasepsi DMPA dengan domain 3 (hubungan sosial) kualitas hidup akseptor kontrasepsi depot medroxyasetat (DMPA) di Bidan Praktik Mandiri Palembang.

Terdapat hubungan antara usia responden dengan domain 4 (lingkungan) kualitas hidup akseptor kontrasepsi depot medroxyasetat (DMPA) di Bidan Praktik Mandiri Palembang.

\section{SARAN}

\begin{abstract}
Penelitian ini perlu dilakukan penelitian lebih lanjut dengan menggunakan desain penelitian kohort prospektif dan melibatkan variabel-variabel lain yang belum diteliti serta menggunakan jumlah sampel yang lebih banyak dan bervariasi.Para pemberi pelayanan perlu meningkatkan konseling terutama mengenai efek samping pemakaian kontrasepsi terhadap akseptor kontrasepsi DMPA terutama untuk usia resiko tinggi dan yang lama penggunaannya $>2$ tahun sehingga para pengguna/akseptor merasa nyaman menggunakan dan kualitas hidup akan tetap tinggi.
\end{abstract}

\section{UCAPAN TERIMA KASIH}

Drg. Nur Adiba Hanum, M.Kes selaku Direktur Poltekkes Kemenkes Palembang, Murdiningsih, SST, SPd, M.Kes selaku Ketua Jurusan Kebidanan sekaligus sebagai konsultan pada penelitian ini, Dr. Drs. Sonlimar Mangunsong, Apt, M.Kes selaku Ketua Unit Penelitian dan Pengembangan Poltekkes Kemenkes Palembang, Semua pihak yang tidak dapat disebutkan satu-persatu yang telah memberikan bantuan moril maupun material sehingga penelitian ini dapat diselesaikan.

\section{DAFTAR PUSTAKA}

Afiyanti, Y. 2010. Analisis Konsep Kualitas Hidup. Jurnal Keperawatan Indonesia, 13, 5.

Bahamondes L, E. A. 2006. A prospective study of the forearm bone density of users of etonorgestrel and levonorgestrel-releasing

contraceptive implants. Human Reproduction, 21.

Bahri Narjes, dkk. 2016. The Relation Between Contraception Methods and Quality of Life, Gonabad-Iran. Epidemiologi Biostatistics and Public Health. vol 13, 4.

Banks Emily, B. A., Casabonne Delphine 2001. Overview of the relationship between use of progestogen-only contraceptives and bone mineral density. British Journal of Obstetrics and Gynaecology, 108.

Dahlan MS. 2011, Statistik untuk Kedokteran dan Kesehatan. Jakarta, Salemba MedikaDelice, A. 2010. The Sampling Issues in Quantitative Research. Departement of Secondary Science and Mathematics Education, 18.

Glasier A, G. A. 2005. Keluarga Berencana dan Kesehatan Reproduksi, Jakarta, EGC.

Kemenkes 2012. Survei Demografi dan Kesehatan Indonesia.

Larasati, T. 2007. Jurnal Kualitas Hidup pada Wanita yang Sudah Memasuki Masa Menopause.

Maiharti RI, Kuspriyanto, 2012. Hubungan Tingkat Pengetahuan, Pendidikan dan Pendapatan dengan Penggunaan Metode Kontrasepsi pada PUS di Kecamatan Jenu dan Kecamatan Jatirogo Kabupaten Tuban. Universitas Negeri Surabaya.

Matsumoto Y, Y. S., Ideta K, Kawabata M 2007. Impact of use of combined oral contraceptive pill on the quality of life of Japanese Woman. Japan 
Society of Obstetrics and Gynecology, 33, 6.

Nofitri, N. 2009. Gambaran Kualitas Hidup Penduduk Dewasa pada Lima Wilayah di Jakarta. Sarjana Psikologi, Universitas Indonesia.

Oktavianus CH. S, N. I. S., Rina K. Kusumaratna, Adi Hidayat 2007. Validitas dan reliabilitas World Health Organization Quality of LifeBREF untuk mengukur kualitas hidup lanjut usia. Universa Medica, 26, 11.

Dinkes, 2015. profil kesehatan 2015. Palembang: dinkes kota palembang.

Prior Jerilynn C, E. A. 2001 Oral contraceptive use and bone mineral density in premenopausal women: cross-sectional, populationbased data from the Canadian Multicentre Osteoporosis Study. CMAJ 8, 165

Saifuddin, A. 2011. Panduan Praktis Pelayanan Kontrasepsi, jakarta, Yayasan Bina Pustaka Sarwono.

Saifuddin A, A. B., ENRIQUITO R 2011. Panduan Praktis Pelayanan Kontrasepsi, Yayasan Bina Pustaka Sarwono.
WHOQOL-GROUP. 1998. Development of the world health organization WHOQOL-BREF Quality Of Life Assesment [Online]. Geneva Switzerland: World Health Organization. [Accessed 20 April 2017].

Pradono J, Hapsari D, dan Sari P, 2009. Kualitas Hidup Penduduk Indonesia Menurut International Classification of Functioning, Disability and Health (ICF) dan Faktor-faktor yang Mempengaruhinya (Analisis Lanjut Data RISKESDAS 2007). Pusat Penelitian dan Pengembangan Ekologi dan Status Kesehatan Jakarta.10

Rohmah AIN, Purwaningsih, Bariyah K, 2012. Kualitas Hidup Lanjut Usia. Jurnal Keperawatan 120-132.

http://www.unpad.ac.id/2013/02/kualitas hidup seseorang terlihat dari interaksi dengan kehidupan disekitarnya/ di akses pada tanggal 16 Desember 2017. 
HASIL PENELITIAN

Hasil Analisis Univariat

Tabel 4.1. Distribusi Frekuensi berdasarkan Karakteristik Responden

\begin{tabular}{lcc}
\multicolumn{1}{c}{ Karakteristik responden } & Jumlah & Persentase \\
\hline Usia & & \\
Risiko tinggi & 19 & 25,3 \\
Risiko Rendah & 56 & 74,7 \\
Pendidikan & & \\
Tinggi & 55 & 73,3 \\
Rendah & 20 & 26,7 \\
Pekerjaan & & \\
Bekerja & 57 & 76 \\
Tidak bekerja & 18 & 24 \\
Penghasilan & & \\
Cukup & 34 & 45,3 \\
Kurang & 41 & 54,7 \\
\hline Total & $\mathbf{1 0 0}$ & $\mathbf{1 0 0}$ \\
\hline
\end{tabular}

Distribusi Frekuensi berdasarkan Lama Penggunaan Kontrasepsi DMPA

Tabel 4.2. Distribusi Frekuensi berdasarkan Lama Penggunaan Kontrasepsi DMPA

\begin{tabular}{|c|c|c|}
\hline Lama Penggunaan & Jumlah & Persentase \\
\hline $\begin{array}{l}<2 \text { tahun } \\
\geq 2 \text { tahun }\end{array}$ & $\begin{array}{l}22 \\
53\end{array}$ & $\begin{array}{l}29,3 \\
70,7\end{array}$ \\
\hline Total & 100 & 100 \\
\hline
\end{tabular}

Distribusi Frekuensi berdasarkan Domain Kualitas Hidup Responden

Tabel 4.3. Distribusi Frekuensi berdasarkan Domain Kualitas Hidup Responden

\begin{tabular}{lcc}
\multicolumn{1}{c}{ Karakteristik responden } & Jumlah & Persentase \\
\hline Domain 1 (Kesehatan Fisik) & 49 & \\
Tinggi & 26 & 65,3 \\
Rendah & & 34,7 \\
Domain 2 (Psikologis) & 59 & 78,7 \\
Tinggi & 16 & 21,3 \\
Rendah & & \\
Domain 3 (Hubungan sosial) & 59 & 78,7 \\
Tinggi & 16 & 21,3 \\
Rendah & & \\
Domain 4 (lingkungan) & 69 & 92 \\
Tinggi & 6 & $\mathbf{1 0 0}$ \\
Rendah & $\mathbf{1 0 0}$ & \\
\hline Total & & \\
\hline
\end{tabular}


Hasil Analisis Bivariat

Hubungan Karakteristik Responden dan lama penggunaan kontrasepsi DMPA dengan Domain 1 (domain kesehatan fisik) Kwalitas Hidup Responden

Tabel 4.4. Hubungan Karakteristik Responden dan lama penggunaan kontrasepsi DMPA dengan Domain 1 (domain kesehatan fisik) Kwalitas Hidup Responden

\begin{tabular}{|c|c|c|c|c|c|c|c|}
\hline & \multicolumn{4}{|c|}{$\begin{array}{c}\text { Kategori Kwalitas Hidup } \\
\text { Domain } 1\end{array}$} & \multirow{2}{*}{\multicolumn{2}{|c|}{ Total }} & \multirow[t]{3}{*}{$P$ value } \\
\hline & \multicolumn{2}{|c|}{ Rendah } & \multicolumn{2}{|c|}{ Tinggi } & & & \\
\hline & $\mathbf{n}$ & $\%$ & $\mathbf{n}$ & $\%$ & $\bar{n}$ & $\%$ & \\
\hline \multicolumn{8}{|l|}{ Usia Responden } \\
\hline Risiko Tinggi & 7 & 36,83 & 12 & 63,2 & 19 & 100 & 1,00 \\
\hline Risiko Rendah & 19 & 3,9 & 37 & 66,1 & 56 & 100 & \\
\hline \multicolumn{8}{|l|}{ Pendidikan } \\
\hline Tinggi & 18 & 32,74 & 37 & 67,3 & 55 & 100 & 0,75 \\
\hline Rendah & 8 & 0,0 & 12 & 60,0 & 20 & 100 & \\
\hline \multicolumn{8}{|l|}{ Pekerjaan } \\
\hline Bekerja & 22 & 38,6 & 35 & 61,4 & 57 & 100 & 0,32 \\
\hline Tidak Bekerja & 4 & 22,2 & 14 & 77,8 & 18 & 100 & \\
\hline \multicolumn{8}{|l|}{ Penghasilan } \\
\hline Kurang & 13 & 31,7 & 28 & 68,3 & 49 & 100 & 0,73 \\
\hline Cukup & 13 & 38,2 & 21 & 61,8 & 26 & 100 & \\
\hline Penggunaan & & & & & & & \\
\hline \multicolumn{8}{|l|}{ Kontrasepsi } \\
\hline$<2$ tahun & 5 & 22,7 & 17 & 77,3 & 22 & 100 & 0,25 \\
\hline$\geq 2$ tahun & 21 & 39,6 & 32 & 60,4 & 53 & 100 & \\
\hline
\end{tabular}

Hubungan Karakteristik Responden dan Lama Penggunaan Kontrasepsi DMPA dengan Domain 2 (domain psikologis) Kwalitas Hidup Responden

Tabel 4.5. Hubungan Karakteristik Responden Lama Penggunaan Kontrasepsi DMPA dengan Domain 2 (domain psikologis) Kwalitas Hidup Responden

\begin{tabular}{|c|c|c|c|c|c|c|c|}
\hline & \multicolumn{4}{|c|}{$\begin{array}{c}\text { Kategori Kwalitas Hidup } \\
\text { Domain } 2\end{array}$} & \multicolumn{2}{|c|}{ Total } & \multirow[t]{2}{*}{$P$ value } \\
\hline & \multicolumn{2}{|c|}{ Rendah } & \multicolumn{2}{|c|}{ Tinggi } & \multirow[b]{2}{*}{$\mathbf{n}$} & \multirow[b]{2}{*}{$\%$} & \\
\hline & $\mathbf{n}$ & $\%$ & $\mathbf{n}$ & $\%$ & & & \\
\hline \multicolumn{8}{|l|}{ Usia Responden } \\
\hline Risiko Tingqi & 6 & 31,6 & 13 & 68,4 & 19 & 100 & 0,21 \\
\hline Risiko Rendah & 10 & 17,9 & 46 & 82,1 & 56 & 100 & \\
\hline \multicolumn{8}{|l|}{ Pendidikan } \\
\hline Tinggi & 9 & 16,43 & 46 & 83,6 & 55 & 100 & 0,11 \\
\hline Rendah & 7 & 5,0 & 13 & 65,0 & 20 & 100 & \\
\hline \multicolumn{8}{|l|}{ Pekerjaan } \\
\hline Bekerja & 11 & 19,3 & 46 & 80,7 & 57 & 100 & 0,51 \\
\hline Tidak Bekerja & 5 & 27,8 & 13 & 72,2 & 18 & 100 & \\
\hline \multicolumn{8}{|l|}{ Penghasilan } \\
\hline Kurang & 7 & 17,1 & 34 & 82,9 & 41 & 100 & 0,48 \\
\hline Cukup & 9 & 26,5 & 25 & 73,5 & 34 & 100 & \\
\hline Penggunaan & & & & & & & \\
\hline \multicolumn{8}{|l|}{ Kontrasepsi } \\
\hline$<2$ tahun & 3 & 13,6 & 19 & 86,4 & 22 & 100 & 0,36 \\
\hline$\geq 2$ tahun & 13 & 24,5 & 40 & 75,5 & 53 & 100 & \\
\hline
\end{tabular}


Hubungan Karakteristik Responden dan Lama Penggunaan Kontrasepsi DMPA dengan Domain 3 (domain Hubungan sosial) Kwalitas Hidup Responden

Tabel 4.6. Hubungan Karakteristik Responden dan Lama Penggunaan Kontrasepsi DMPA dengan Domain 3 (domain Hubungan sosial) Kwalitas Hidup Responden

\begin{tabular}{|c|c|c|c|c|c|c|c|}
\hline & \multicolumn{4}{|c|}{$\begin{array}{c}\text { Kategori Kwalitas Hidup } \\
\text { Domain } 3\end{array}$} & \multirow{2}{*}{\multicolumn{2}{|c|}{ Total }} & \multirow[t]{3}{*}{$P$ value } \\
\hline & \multicolumn{2}{|c|}{ Rendah } & \multicolumn{2}{|c|}{ Tinggi } & & & \\
\hline & $\mathbf{n}$ & $\%$ & $n$ & $\%$ & $\bar{n}$ & $\%$ & \\
\hline \multicolumn{8}{|l|}{ Usia Responden } \\
\hline Risiko Tinggi & 8 & 42,1 & 11 & 57,9 & 19 & 100 & 0,02 \\
\hline Risiko Rendah & 8 & 14,3 & 48 & 85,7 & 56 & 100 & \\
\hline \multicolumn{8}{|l|}{ Pendidikan } \\
\hline Tinggi & 11 & 20,02 & 44 & 80,0 & 55 & 100 & 0,75 \\
\hline Rendah & 5 & 5,0 & 15 & 75,0 & 20 & 100 & \\
\hline \multicolumn{8}{|l|}{ Pekerjaan } \\
\hline Bekerja & 12 & 21,1 & 45 & 78,9 & 57 & 100 & 1,00 \\
\hline Tidak Bekerja & 4 & 22,2 & 14 & 77,8 & 18 & 100 & \\
\hline \multicolumn{8}{|l|}{ Penghasilan } \\
\hline Kurang & 8 & 19,5 & 33 & 80,5 & 41 & 100 & 0,88 \\
\hline Cukup & 8 & 23,5 & 26 & 76,5 & 34 & 100 & \\
\hline Penggunaan & & & & & & & \\
\hline \multicolumn{8}{|l|}{ Kontrasepsi } \\
\hline$<2$ tahun & 1 & 4,5 & 21 & 95,5 & 22 & 100 & 0,02 \\
\hline$\geq 2$ tahun & 15 & 28,3 & 38 & 71,7 & 53 & 100 & \\
\hline
\end{tabular}

Hubungan Karakteristik Responden dan Lama Penggunaan Kontrasepsi DMPA dengan Domain 4 (domain lingkungan) Kwalitas Hidup Responden.

Tabel 4.7. Hubungan Karakteristik Responden dan Lama Penggunaan DMPA dengan Domain 4 (domain lingkungan) Kwalitas Hidup Responden

\begin{tabular}{|c|c|c|c|c|c|c|c|}
\hline \multirow[t]{3}{*}{$\begin{array}{l}\text { Karakteristik } \\
\text { Responden }\end{array}$} & \multicolumn{4}{|c|}{$\begin{array}{c}\text { Kategori Kwalitas Hidup } \\
\text { Domain } 4\end{array}$} & \multirow{2}{*}{\multicolumn{2}{|c|}{ Total }} & \multirow[t]{3}{*}{$P$ value } \\
\hline & \multicolumn{2}{|c|}{ Rendah } & \multicolumn{2}{|c|}{ Tinggi } & & & \\
\hline & $\mathbf{n}$ & $\%$ & $\mathbf{n}$ & $\%$ & $\mathbf{n}$ & $\%$ & \\
\hline \multicolumn{8}{|l|}{ Usia Responden } \\
\hline Risiko Tinggi & 4 & 21,1 & 15 & 78,9 & 19 & 100 & 0,03 \\
\hline Risiko Rendah & 2 & 3,6 & 54 & 96,4 & 56 & 100 & \\
\hline \multicolumn{8}{|l|}{ Pendidikan } \\
\hline Tinggi & 3 & 5,5 & 52 & 94,5 & 55 & 100 & 0,33 \\
\hline Rendah & 3 & 15,0 & 17 & 85,4 & 20 & 100 & \\
\hline \multicolumn{8}{|l|}{ Pekerjaan } \\
\hline Bekerja & 5 & 8,8 & 52 & 91,2 & 57 & 100 & 1,00 \\
\hline Tidak Bekerja & 1 & 5,6 & 17 & 94,4 & 18 & 100 & \\
\hline \multicolumn{8}{|l|}{ Penghasilan } \\
\hline Kurang & 3 & 7,3 & 38 & 92,7 & 41 & 100 & 1,00 \\
\hline Cukup & 3 & 8,8 & 31 & 91,2 & 34 & 100 & \\
\hline \multirow{2}{*}{\multicolumn{8}{|c|}{ Kontrasepsi }} \\
\hline & & & & & & & \\
\hline$<2$ tahun & 0 & 0,0 & 22 & 100 & 22 & 100 & 0,17 \\
\hline$\geq 2$ tahun & 6 & 11,3 & 47 & 88,7 & 53 & 100 & \\
\hline
\end{tabular}

